Paideusis

\title{
How to Domesticate Otherness: Three Metaphors of Otherness in the European Cultural Tradition
}

\section{Robi Kroflic}

Volume 16, Number 3, 2007

URI: https://id.erudit.org/iderudit/1072487ar

DOI: https://doi.org/10.7202/1072487ar

See table of contents

Publisher(s)

Canadian Philosophy of Education Society

ISSN

0838-4517 (print)

1916-0348 (digital)

Explore this journal

Cite this article

Kroflic, R. (2007). How to Domesticate Otherness: Three Metaphors of Otherness in the European Cultural Tradition. Paideusis, 16(3), 33-43. https://doi.org/10.7202/1072487ar

\section{Article abstract}

Individual and collective identities always develop in relation to the other as different, and in this process, the otherness is always subjected to the attempts of cultivation/domestication. In the history of European thought, we can recognize three metaphors which express the impossibility of seeing the other as different: the metaphors of The Leper, The Court Fool and The Noble Savage. They developed on the basis of the relationship between the difference and common rationality, which means that a more inclusive relationship to otherness as a conversational ideal could be formed if we were able shift the emphasis of ethical discourse from the universal concept of autonomy to respect for authenticity and to Levinas's ethics of "the face of the other". Such a step requires a radical change of discursive practices of all involved in the educational processes. That is why I propose the principle of observing the face of the other as different in both real-life experience and in expressive images of art, as well as the recognition and acceptance of otherness at the very core of our own identity.
This document is protected by copyright law. Use of the services of Erudit (including reproduction) is subject to its terms and conditions, which can be viewed online.

https://apropos.erudit.org/en/users/policy-on-use/ 


\title{
How to Domesticate Otherness: Three Metaphors of Otherness in the European Cultural Tradition
}

\author{
ROBI KROFLIČ \\ University of Ljubljana, Slovenia
}

\begin{abstract}
Individual and collective identities always develop in relation to the other as different, and in this process, the otherness is always subjected to the attempts of cultivation/domestication. In the history of European thought, we can recognize three metaphors which express the impossibility of seeing the other as different: the metaphors of The Leper, The Court Fool and The Noble Savage. They developed on the basis of the relationship between the difference and common rationality, which means that a more inclusive relationship to otherness as a conversational ideal could be formed if we were able shift the emphasis of ethical discourse from the universal concept of autonomy to respect for authenticity and to Levinas's ethics of "the face of the other". Such a step requires a radical change of discursive practices of all involved in the educational processes. That is why I propose the principle of observing the face of the other as different in both real-life experience and in expressive images of art, as well as the recognition and acceptance of otherness at the very core of our own identity.
\end{abstract}

"It is not by confining one's neighbour that one is convinced of one's own sanity." (F. M. Dostoyevsky, The Diary of a Writer)

There is a surprising level of agreement today among the key authors in anthropological sciences on the importance of the attitude towards the other in the formation of individual and collective identities. And, although in this context we would tend to think first of the idealised image of the significant other, i.e. a familiar person as the source of protection and feelings of kinship and love, the other is always also the harbinger of the external which demands, forbids, restricts, and "domesticates" the individual's subjectivity in one way or another (Nastran-Ule, 2000, pp. 28-33). The domestication which, according to Foucault, operates through various systems of disciplining and control has two main directions. On the one hand, the notions, customs, and norms of the reference group are imparted to the new member of the community; and on the other, the community struggles to maintain a stable identity by labelling everybody who is not its member as radically different, uncivilised, barbaric. The words barbaros itself is onomatopoetic ("one who speaks blab-blab"), and to the Greeks of the $7^{\text {th }}$ and $6^{\text {th }}$ centuries $\mathrm{BC}$ it meant someone who speaks an unintelligible, even illogical language; one who babbles.

But the history of European thought warns us of yet another phenomenon. As long as a culture assumes a radically repressive attitude towards those who are different, such attitude will be critically reflected particularly through art, advising the humanity against the intolerable inhuman treatment of one's neighbour as different. But once the excluding attitude is "humanised" and less repressive forms

(C) Copyright 2007. The author, Robi Kroflic, assigns to Paideusis the right of first publication and educational and non-profit institutions a non-exclusive license to use this document for personal use and in courses of instruction provided that the article is used in full and this copyright statement is reproduced. Any other usage is probibited without the express permission of the author. 
of exclusion are applied, the critical reflection of exclusion declines. This is particularly true in periods when the prevailing view of the other is one of the "noble savage", the object of fascination evoking the illusion of closeness to genuine, unspoilt nature, to a tourist destination which can be visited and then abandoned, not requiring a deeper personal involvement or a realisation of the necessity of coexistence with otherness in a globalised world. A theoretical deconstruction of the historical attitudes of exclusion therefore seems particularly important today; only through it we can develop the muchneeded sensitivity to our relationships with the other, without which we cannot base education on the humanist principles of the modern educational theory and the agreed upon civilised principles of dignity of every individual or culture.

\section{What is the Basis of the Exclusive Attitude Towards the Other?}

One of the stories in Milan Kundera's (1983) Book of Laughter and Forgetting describes the life of the pure girl Tamina, who after many disappointments in the real world arrives at a fantasy island of innocence inhabited only by children. But fairly soon the children's innocence proves to be very painful, since the children spontaneously include her in their play, which becomes increasingly insensitive to Tamina's feelings and physical pain: they pinch and bite her, and innocently include her in their little sexual games. At the end, the author poses the following question:

Why are the children so bad?

But they are not all that bad. In fact, they're full of good cheer and constantly helping one another. None of them wants Tamina for himself. "Look, look!" they call back and forth. Tamina is imprisoned in a tangle of nets, the ropes tear into her skin, and the children point to her blood, tears and face contorted with pain. They offer her generously to one another. She has cemented their feelings of brotherhood.

The reason for her misfortune is not that the children are bad, but that she does not belong to their world. No one makes a fuss about calves slaughtered in slaughterhouses. Calves stand outside human law in the same way Tamina stands outside the children's law.

If anyone is full of bitterness and hate, it is Tamina, not the children. Their desire to cause pain is positive, exuberant: it has every right to be called pleasure. Their only motive for causing pain to someone not of their world is to glorify that world and its law."

(Kundera, 1983, p. 185)

Kundera's line of thought raises a number of questions:

- What is the role of facing otherness in the development of individual identity and in the formation of community?

- Is insensitive or even intolerant attitude of an individual (or a homogeneous community) towards otherness connected to moral perversion (being bad), or is it a "naturally innocent" reaction towards otherness as a threat to one's own self-image?

- If the latter opinion is more correct, as Kundera suggests, can the development of personality (or collective consciousness) change our attitude towards otherness and make us more sensitive to pain and joy of the different other?

- And then, what is the role of the recognition of our own internal division and "handicap", i.e. the otherness at the very core of our identity, in this development?

As a pedagogue, I am particularly interested in the question whether and in what manner a more inclusive attitude towards any kind of otherness can be developed; my line of thought is therefore based on the following hypotheses: 
- Both individual and collective identities are always developed in relationship to the other as different, by attempting to cultivate or "domesticate" this difference in one way or another.

- The prevailing historical forms of the cultivation of otherness have their recognisable metaphoric forms, which invariably express the inability of accepting the other as different.

- The development of an open-minded attitude towards difference is inextricably linked to the understanding of the significance of the failed historical encounters with otherness on one hand and to the discovery and acceptance of difference at the very core of our own identity.

- Our attitude towards otherness is the fundamental catalyst of the development of active tolerance and an inclusive culture of our societies.

It is my hope that my thoughts here will at least contribute to a better understanding of the darker sides of the failed contacts with otherness, which are so characteristic of the Western spiritual tradition.

\section{Historical Metaphors of the Exclusive Attitude Towards Otherness}

On the following pages, I will present our topic through a number of metaphors, provided in the most persuasive way by art. I should probably begin with the first mythological depiction of otherness in Antiquity, i.e. Medea by Euripides (431 BC). In the light of the present-day interpretations, two kinds of otherness, which characterise the European civilisation, are intertwined here. Medea is first described as different and barbaric because she is a foreigner; despite her noble help to Jason, she cannot abolish the fact that she is not Greek and is therefore led by brute force, not by rational judgement:

Not one amongst the wives of Hellas e'er had dared this deed; yet before them all I chose thee for my wife, wedding a foe to be my doom, no woman, but a lioness fiercer than Tyrrhene Scylla in nature. (Euripides)

On another occasion, Jason's desperate eyes see Medea as different because she is a woman, as exemplified in his following statement:

Yea, men should have begotten children from some other source, no female race existing; thus would no evil ever have fallen on mankind. (Euripides)

Since I intend to follow Foucault's suggestion that in the European tradition, the attitude towards otherness, be it "madness, crime or disease," is established on the "caesura that establishes the distance between reason and non-reason" (Foucault, 1973, pp. IX-X), we can see that this caesura was already there in Antiquity, although it will only adopt the decisive role as the criterion of exclusion after Descartes. It is also true that Antiquity retained some ambivalence in its attitude to otherness as nonreason. Medea as the barbarian and irrational child-murderer can be compared to another rebellious female figure: Antigone, who also transgresses the social convention, but is also the first figure to explicitly exemplify the conflict between the heteronomous and autonomous morality. While Sophocles could not provide a decisive answer to the question whether her autonomous stance was founded on rationality or on the Dionysian dimension of eros (cf. Kroflič, 1997, 2005), it is nevertheless certain that, despite their faith in man's dispassionate and rational nature as embodied in the Apollinarian cult, 
the Greeks still acknowledged the positive role of the bybris and the Dionysian cult, and considered both important for the further development of civilisation.

According to Foucault, various facets of the attitude towards otherness as unreason truly came to the fore in the late Middle Ages and the Renaissance, and later particularly in the period of the Enlightenment, when modern thought began to face its own contradictions.

According to Foucault, the motif that best describes the Renaissance attitude towards the otherness (otherness as unreason) is the Ship of Fools, which could have been seen in both literary or visual artistic forms ever since the end of the fifteenth century. Two characteristic European metaphors of otherness combine in it, those of The Leper and The Court Fool.

Both metaphors "symbolized a great disquiet, suddenly dawning on the horizon of European culture at the end of the Middle Ages. Madness and the madman become major figures, in their ambiguity: menace and mockery, the dizzying unreason of the world, and the feeble ridicule of men." (Foucault, 1973, p. 13)

The Madman, The Fool, The Simpleton are put to the centre of the theatre as the bearers of truth:

In a comedy where each man deceives the other and dupes himself, the madman is comedy to the second degree: the deception of deception; he utters, in his simpleton's language which makes no show of reason, the words of reason that release, in the comic, the comedy: he speaks love to lovers, the truth of life to the young, the middling reality of things to the proud, to the insolent, and to liars. Even the old feasts of fools, so popular in Flanders and northern Europe, were theatrical events, and organized into social and moral criticism, whatever they may have contained of spontaneous religious parody. (Foucault, 1973, p. 14)

The Fool is therefore the person who is permitted to speak the truth, and it is not surprising that in the first edition of Brant's satire Narrenschiff (1497), an engraving depicts the author as a scholar surrounded by books and dressed as a university professor, whose cap from behind has the typical shape of the court jester's cockscomb (see http://www.tcd.ie/Modern_History/Postgrad/Mphil/webpage/ bookfooll.gif).

The period that we are talking about had a whole set of historically famous "fools," of which I would like to point out at least two - from the areas of science and art. One of the key Renaissance philosophical works that strived to affirm the rational nature of the humanity is The Praise of Folly by Erasmus of Rotterdam, and in the area of literature, Cervantes's Don Quixote stands out as the work which is today considered one of the first European novels. The consecrated status of folly can also be seen in the popular attitudes towards epilepsy as the "sacred disease", which are particularly deeply rooted in Orthodox Christianity; we need only think of Prince Miskin in Dostoevsky's novel The Idiot.

The described ambivalence of folly remained in place even after they began to expel the fools from townships with ships; in this practice, folly was connected with yet another metaphor, that of The Leper. The most interesting depiction of the access to truth which is reserved for the expelled fool is certainly the tree placed by Hieronymus Bosch on the Ship of Fools (see http://www.ibiblio.org/ $\mathrm{wm} / \mathrm{paint} / \mathrm{auth} / \mathrm{bosch} /$ fools) in place of the mast, which can be interpreted as the symbol of the biblical tree of knowledge of good and evil (see the commentary on Bosch's painting at http://www.artdamage.com/bosch/ship2.htm). The motif of the tree of knowledge on the ship of fools also appears in certain other pictures and engravings from that period (Foucault, 1973, p. 22). Foucault is convinced that after leprosy had been eradicated in Europe, the role of The Leper was assumed by poor vagabonds, criminals, and "deranged minds" (Foucault, p. 7), and that the metaphor of The Leper combined the care for healing with the care for exclusion: "It is possible that the village of Gheel developed in this manner-a shrine that became a ward, a holy land where madness hoped for deliverance, but where man enacted, according to old themes, a sort of ritual division." (Foucault, p. 10) And while in relation to the pilgrimage site of Gheel, Foucault only makes educated guesses on the 
basis of existing historical documents, the combination of the care for healing and the care for exclusion became an empirical fact in the seventeenth-century Europe, when the "Hôpital" began to emerge, as well as psychiatry in the nineteenth century; with the "great confinement", the classical age "was to reduce to silence the madness whose voices the Renaissance had just liberated, but whose violence it had already tamed" (Foucault, p. 38).

The European culture of the modern age established yet another metaphor of otherness, that of The Noble Savage. Although Christian Europe maintained a negative image of the barbarian as an uncivilised, wild being, the Crusades brought about not only the stories of conquest and civilisation of barbarian lands, but also of a quest for one's own roots; what is more, a quest for "the lost wonderful, primeval and innocent world..." (Zaviršek, 2000, p. 67) The fascination with the uncivilised yet innocent natural state emerged as early as the Enlightenment when, for example, Rousseau in his Discourse on the Origin and Basis of Inequality Among Men attributed moral deprivation to the negative influences of the human world; but the vision was strengthened at the turn of the nineteenth century, when the awareness of the negative side effects of civilisation and enculturation grew, and The Noble Savage became the image of human liberated from the "ballast of culture" (Zaviršek, p. 68).

In the nineteenth and twentieth century, the interest in the world of The Noble Savage entered everyday life (the "empathic" fascination with a physically deformed and therefore "uncivilised" individual in Victorian England was brilliantly illustrated in David Lynch's 1980 film The Elephant Man) and scientific discourse (Grosrichard's Structure of the Seraglio describes fascination with the oriental forms of government, Levi-Strauss's Savage Mind breaks down the myth of the unintelligent nature of the totemic man). Of course, the topic also appeared in art. Gauguin's Vairaumati (see http://www. classicartrepro.com/data/large/Gauguin/Vairaumati.jpg) certainly expresses his deep conviction of civilisation beyond European notions and of the equality of mythological and religious views of the origins of man. But although Gauguin had spend a lot of time in Tahiti and also died there, we cannot help having the impression that the figure of The Noble Savage remained the figure of otherness beyond our own world: the figure of the native as an ideal object of tourist attraction in which the civilised man of the twentieth century seeks the remains of the "unspoilt nature" in both the physical and cultural senses of the word.

Having described the attitudes to otherness and the manners in which it was depicted in art, Foucault concludes his History of Madness in the Classical Age in a very illuminating way:

There is no madness except as the final instant of the work of art - the work endlessly drives madness to its limits; where there is a work of art, there is no madness; and yet madness is contemporary with the work of art, since it inaugurates the time of its truth. The moment when, together, the work of art and madness are born and fulfilled is the beginning of the time when the world finds itself arraigned by that work of art and responsible before it for what it is.

Rise and new triumph of madness: the world that thought to measure and justify madness through psychology must justify itself before madness, since in its struggles and agonies it measures itself by the excess of works like those of Nietzsche, of Van Gogh, of Artaud. And nothing in itself, especially not what it can know of madness, assures the world that it is justified by such works of madness. (Foucault, 1973, pp. 288-289)

What do the prevailing metaphors of otherness in the European tradition tell us? The Leper became an undesirable metaphor in the twentieth century, because its caesura of exclusion is too obvious; but at the same time, the acknowledgement that madness may establish an "alternative field of rationality" was lost, as postulated most clearly by the antipsychiatric movement. The Court Fool survived in the roles of the local eccentric and the clown, who are allowed to speak about the unspeakable truths of existence at the price of exclusion from the normalised community. The metaphor of The Native, however, experienced a boom, not only in the form of the tourist attraction based on the suppressed myth of the noble savage and the original natural existence, but also in the attitude to people with 
special needs and to members of certain minority cultures (the Romany in Europe, for example). The fact that the discourse of medicine readily recognises Romany children as children with special needs (Save the Children, 2001) is masked by the cliché of a romantic, indigenous culture of music and dance. Even more - the true Romany musician should be, according to this illusion, incapable of reading musical scores (supposedly the basis of civilised achievement in musical art), which makes him an example of natural musicianship coming directly "from the heart".

The same dimension is described by Rutar in the attitude to persons with special needs:

The very idea of integration is unbearably stale and anaemic. Is the Latin root, integer, from which the word integration is derived, itself not illustrative enough? It means "immaculate, unblemished, unspoilt," even "unbribable" and "passionless." The idea is stale because it presumes that the society is a flourishing, virginal, unselfish, and flagrant meadow in which integration is necessary because of some civilisational blunders which were unfortunately incurred by certain groups of people. Through integration, we return to the previous uncurtailed and undamaged state; that is why all the maudlin and melancholic images of beautiful youth, unspoilt paradise, genuine nature, etc. are attached to it. (Rutar, 1995, p. 15)

Rutar is convinced that such view of otherness is "connected to the imagery and fed by the prejudice and stereotypes of who we are". Perhaps the twentieth century really disposed of the worst forms of exclusion derived from the metaphor of The Leper; perhaps it disposed of the happy concept of assimilation - or the melting pot as the theoretical model of new political associations typical of the emergence of the United States of America. But this does not mean that we have become "reconciled" with otherness and succeeded in establishing an inclusive culture of coexistence in a global society and school.

The overview of the key metaphors of otherness should remind us of the kind of uneasiness which is particularly typical of the most exclusive models and which art has continued to expose throughout history. The basic view of otherness as reflected in various kinds of discourse is simply forced to face this uneasiness which stems from the universalist theories of civilisation and the cultured individual, which exclude anybody who is not "domesticated" or did not wholly accept the conventional ways of socialised life. According to Norbert Elias (2000-2001), socialised life always entails an inclusion of a series of social constraints into one's registry of self-coercion, and I agree with Rutar that the Enlightenment is "... impossible, because there is no common knowledge of what the people should make common ..." (Rutar, 1995, p. 11). The solutions should be brought about by changes in the symbolic, i.e. in the discursive practices through a deconstruction of our historical narratives (Gergen, 1998).

\section{How to Domesticate Otherness?}

If we take the concept of inclusion as the basis for a new culture of coexistence, we should keep in mind the observation of Siegel (1995) that the concept of inclusion appeared in various theoretical papers to emphasise the importance of the particular and to criticise the universalistic discourse of modern humanism and social sciences. The core of this criticism is the observation that the universalistic discourse strives to define the common characteristics of all people, overlooking the peculiarities of different, particularly marginalised groups and individuals and excluding their views, values, needs, and opinions. This is ethically intolerable, therefore inclusion "...should be embraced as a conversational ideal because it is morally wrong to exclude people from, or silence them in, conversations in which they have an interest or stake" (Siegel, p. 3).

The pre-modern and modern universalism links the attitude towards otherness to a universal model of rationality, even when dealing with ethical principles and communicative practices. That is 
why in contemporary philosophy we often encounter arguments that the classical universalistic model of deontological ethics as established by Kant has been exhausted and cannot serve as a basis for the formation of an inclusive dialogue. If we understand the otherness of our neighbour as connected to his/her authentic life position as a being, characterised by his/her care for him/herself and the quest for a personal life sense (Kroflič, 2005, p. 26), we can further develop Foucault's statement that it was Descartes's faith in the universal rational method that definitively excluded the contingent otherness. David E. Cooper in his apology of authenticity - as the necessary antipode of the universalistic concept of autonomy - highlights one of the fundamental flaws of Kant's ethics, namely his conviction that the laws legitimated by the autonomous person for him/herself are those that are common to all rational beings as such - that they are therefore the universal laws of reason (Cooper, 1998, p. 65, cf. also Kroflic 2005, p. 25). Indeed, a model of ethics which is based on the faith in uniform rationality of the autonomous subject is particularly prone to the exclusion of those individuals or groups which for any personal or culturally-specific reason develop an alternative life sense, life style, or communicative code.

In last decades two different answers to the question of just treatment of otherness appeared in theoretical discourse. The first searches for a rationality of ideal/inclusive discourse, where all different voices of authentic individuals can be heard (Habermas). For this kind of ethical negotiation Strike proposes a demand for a minimal, but thick enough conception of common good, together with hermeneutical understanding of otherness of persons that are involved in ethical negotiation (Strike, 1998). The other answer is philosophically even more ambitious. It is a search for a new concept of subjectivity and a kind of pre-ethical acceptance of otherness of every individual as a basis of responseability and empathically sensitive and respectful attitude toward the Other. I would like to conclude this article with a brief presentation of basic philosophical ideas and pedagogical consequences of this second approach that aroused in a close dialogue with Levinas anthropological ideas.

One of the most original ethical theorists of the second half of the twentieth century, Levinas, sees the solution to the described historical problem of exclusion of otherness in the shift of the starting point of ethical discourse from the universalistic rational principle to the face of our fellow human, for what it is necessary to find an alternative model of human subjectivity and moral responsibility.

We can take Bai's (Bai 2002, pp. 19-20) diagnosis of the problem of the Kantian autonomous subject as atomistic individual, for which self-identity precedes social relationships, to argue for Levinas's turn in philosophy. According to Levinas, authentic subjectivity is evoked by the face of the Other, which means, that we come into presence through responding, through taking up - or not denying - the undeniable responsibility which precedes our subjectivity (Biesta, 2006). Levinas's second important thesis is that of the Other as absolute difference: "The Other as Other is not only an alter ego: the Other is what I myself am not. The Other is this, not because of the Other's character, or physiognomy, or psychology, but because of the Other's very alterity" (Levinas, 1987, p. 83). According to this thesis, Chalier warns us that Kantian moral subjects are likely to commit the error of seeing the other as their alter ego, therefore "... the other deserves my respect because of his or her rationality, his or her capability of being an autonomous person like myself," and not because of "the otherness of the other" (Chalier, 2002, p. 68). Todd finally claims that the Other is "infinitely unknowable", but anyway susceptibility to absolute difference defines how we relate to each other; even more, learning from the unknowable Other tells us who we really are (Todd 2003, p. 3 and 34). Third Levinas's thesis is a logical consequence of the first two, that responsibility as respect for the other and the whole world is not the result (of accepting ethical standards), but the condition of ethics: “...the reciprocity of respect is not an indifferent relationship, ... and it is not the result, but the condition of ethics... Respect attaches the just man to his associates in justice before attaching him to the man who demands justice" (Levinas 2006, p. $30)$.

If rationality cannot or should not be the measure of humanity (Biesta, 2006, p. 9) and our ethical consciousness, although valuable, is not the basis of human response to the Other, how can we provoke a change in our discursive practices toward the Other as radically different and unknowable 
and create inclusive educational environments? My hypothesis is that a change in discourse, understood as a mental scheme or the form of interpretation of a certain phenomenon or project, defining the strategies for problem-solving and achieving the fundamental objectives (Fulcher, 1989, p. 8), requires a reinterpretation of the recognised exclusive practices and facing the otherness at the very core of our own personality or life story.

One of the most promising answers to the demand for changing exclusive discursive practices in the field of educational theory is the development of the so-called relational pedagogy, which rejects the view of a person and as a relatively fixed structure and relations as logical consequences of our rational intentions (Bingham \& Sidorkin, 2004). In the manifesto of relational pedagogy we can find statements that completely affirm Levinas anthropological thought: that human beings and non-human things acquire reality only in relation to other beings and things; that the self in a knot in the web of multiple intersecting relations; that human relations exist in and through shared practices; that human words and actions acquire meaning only in a context of specific relations; that teaching is building of educational relations; and finally, that human relationality is not an ethical value, because domination is as relational as love (ibid., pp. 5-7), what warns us to build an educational relation in responsibility to avoid existing discourses of domination and exclusion. From the relational view on mutual causality, according to Bai, every pedagogical and ethical situation strengthens pro-social motivation of individuals, because

when we think the self is alone ... responsibility becomes a burden, a liability, a cost to the self. It takes the sacrifice to the self ... [while] ... responsibility [for a person of mutual causality] is not so much discharging a duty or paying for one's existence but fulfilling his potential in being a particular part of the whole. What he is doing is not so much taking on responsibility as fulfilling the potential of the being inscribed in the position he currently occupies in his moral universe. (Bai, 2002, p. 22)

Finally, I would like to sketch a brief answer to the question of how to build a response-able and pro-socially oriented person who will accept otherness of a fellow being without fear and denial, and with the feeling and understanding that relation with otherness is a path to self-fulfilment and personal growth.

Creating inclusive educational environments is, according to Biesta, related to the confirmation of otherness as a condition of just and democratic social environment: "Democracy itself is, after all, a commitment to a world of plurality and difference, a commitment to a world where freedom can appear" (Biesta, 2006, p. 151). This does not mean that we can totally avoid the fact that every rational community produces strangers, who do not fit the cognitive, moral, or aesthetic map of the world (Bauman, 1995, quoted in Biesta, p. 58). But, Biesta claims, we can enable the existence of the other community inside the rational community as a constant possibility that comes into presence as soon as one responds to the other, to the otherness of the other, to what is strange in relation to the discourse and logic of the rational community" (Biesta, 2006, p. 66).

On the individual level, creating openness to otherness of the Other requires a methodical approach to the development of pro-social orientation and ethical responsibility of pupil that is different from prevailing scientific models, rooted in the enlightenment anthropology. If we combine Levinas' insight that responsibility as respect for the other and the whole world is not the result but the condition of ethics and moral consciousness with psychological investigations of a pre-school child that confirm a child's pro-social orientation toward the fellow person long before the development of moral cognitive structures that enable rational confirmation of just statements and actions (and not amoral apathy as Piaget has claimed decades ago), we can confirm a three stage model of moral education:

- if ethical consciousness demands complex cognitive capacities of a moral subject (even of a child in its first years), then developing the capability of forming relations of love and friendship, through which he/she develops relational response-ability and 
normative agency for pro-social activities, in the most authentic way;

- because personal relations can be harmful with respect to the possibility of empathic over-arousal, empatbic bias, pity and paternalism, the next step in promoting moral responsibility is the development of the sense of respect toward concrete persons (their faces) or activities;

- the last step of moral education is to become aware of ethical principles and humanistic demands, concerning especially human rights and ecological values, and to learn how to use them as basis for democratic negotiations in cases of interpersonal conflicts (Kroflič, 2007, pp. 67-68).

A special point of this development is the inductive approach that enables to recognize important differences between enlightenment's concept of discipline and cultivation as domestication of otherness, on one side, and education that enables every child to come into the world as unique individual through responsible responses to what and who is other and different, on the other side (Biesta, 2006). In the project European Multiple Choice Identity (see http://www.europemci.com/) we try to concretize this approach, as the following quotation elaborates:

When we speak about promoting identity building processes and especially the moral development that is incorporated in it we cannot but enter the realm of indoctrination. Even theorists of liberal education like Guttman admit that it is impossible to educate in the field of moral development without a minimum of enforcement of common goals and moral standards. But what we are doing in a different way as most common projects until now is that we don't begin with necessary strict moral standards that everybody must accept, but with sense opening for every individual position in the interconnected world of differences. We promote opportunities for pro-social behaviour, for growing reflection of conflicts, and possibilities for common living on the basis of active tolerance, where empowerment of individual position of everyone and commitment to pro-social behaviour are the mill stones of our identity. We should stay inside the framework of human rights and enforce weaker 'should obligations' to respect human rights to become stronger 'must moral imperatives'. (Kroflič \& Kratsborn, 2006, p. 156)

In our project a special educational role of identity development belongs to aesthetics. As we saw in the first part of this article, artists provide us with strong experiences through the language of artistic imagination, narration, and metaphors. As Greene (1995, pp. 132, 183) claims, artistic imagination leads us to the life stories of Others, to imaginative "as if" worlds which warn us that world in which we live is built from the simultaneous presence of numerous perspectives, so pupils have to search for their voices and play participatory and articulated roles in a rising community.

I would like to close this article by emphasizing again the importance of the individual's encounters with otherness in an inclusive environment through concrete relationships and artistic imagination. If we combine educational requirements with the fundamental principles of Levinas's ethics, we may arrive at the conclusion that Felc, a distinguished Slovenian psychiatrist, himself being a person with special needs, expressed poetically:

There is no true otherness, because practically everybody is different in one way or another... Handicap and death are two conditions that disillusion dictators and keep the philosophers and ideologists of all kinds busy. Yes, they bring the elites of humankind down to earth, to at least one conclusion: that we are all in the same boat, and therefore equal - irreversibly equal in our differences. (Felc, 1995, pp. 95-96) 
Perhaps the best way to become aware of our otherness is, as Levinas would put it, meeting the face of the Other as different, in the real world or in the expressive images of art!

\section{References}

Bai, H. (2002). Taking one's place in a moral universe. Philosophy of Education. Retrieved on November 1, 2007, from http://www.ed.uiuc.edu/EPS/PES-yearbook/2002/19-bai\%2002.pdf

Biesta, G. J. J. (2006). Beyond learning: Democratic education for a buman future). Boulder, CO: Paradigm Publishers.

Chalier, C. (2002). What ought I to do? Morality in Kant and Levinas. Ithaca: Cornell University Press.

Cooper, D. E. (1998). Authenticity, life and liberal education. In P. H. Hirst \& P. White (Eds.), Philosophy of education: Mayor themes in the analytic tradition. Volume II. Education and buman being (pp. 32-67). London: Routledge.

Elias, N. O. (2000-2001). procesu civiliziranja. Ljubljana: Založba.

Euripides. Medea. Translated by E. P. Coleridge. Retrieved on November 1, 2007, from http://www. sacred-texts.com/cla/eurip/medea.htm

Felc, J. Jaz in drugačnost. (1995). Edina prava ljubezen je ljubezen do drugǎ́nih. Ljubljana: Vitrum.

Foucault, M. (1973). Madness \& civilization. A bistory of insanity in the age of reason. New York: Vintage Books.

Fulcher, G. (1989). Disabling policies? A comparative approach to education policy and disability. London: The Falmer Press.

Gergen, K. J. (1989). Narrative, moral identity and historical consciousness: A social constructionist account. In Straub, J. (Ed), Identität und historisches Bewusstsein. Frankfurt: Suhrkamp. (Also: http://www.swarthmore.edu/SocSci/kgergen1)

Greene, M. (1995). Releasing the imagination: Essays on education, the arts, and social change. San Francisco: Jossey-Bass.

Kroflič, R. (1997). Avtoriteta v vagoji. Ljubljana: Znanstveno in publicistično središče.

Kroflič, R. (2005). Is autonomy still an acceptable education and socialization goal of public education? Contemporary Pedagogy, 5, 19-35.

Kroflič, R. (2007). Vzgoja za odgovornost onkraj razsvetljenske paradigme : od razvoja odgovorazmožnosti k spoštljivemu odnosu in razvoju etične zavesti. Sodobna pedagogika, 58, 56-71.

Kroflič, R., \& Kratsborn, W., (2006). "Razprava na Agori” o identiteti mnogoterih izbir. Dvatisoč (Evropa strpnost ali sožitje?), 186, 187, 188, 150-156.

Kundera, M. (1983). The book of laughter and forgetting. Harmondsworth: Penguin.

Levinas, E. (1987). Time and the Other and additional essays. Pittsburgh: Duquesne University Press.

Levinas, E. (2006). Entre nous. London: Continuum.

Nastran-Ule, M. (2000). Sodobne identitete v vrtincu diskurzov. Ljubljana: Znanstveno in publicistično središče.

Rutar, D. O solidarnosti in drugačnosti (1996). Edina prava ljubezen je bjubezen do drugǎ̌nih. Ljubljana: Vitrum.

Save the Children. (2001). Denied a future? The right to education of Roma/Gypsy \& Traveller Children in Europe. London: Author.

Siegel, H. (1995). What price inclusion? Philosophy of education. Retrieved on November 1, 2007, from http://w3.ed.uiuc.edu/eps/pes-yearbook/95_docs/siegel.hkml

Strike, K. A. (1998). On the construction of public speech: pluralism and public reason. In P. H. Hirst \& P. White (Eds.), Philosophy of education: Major themes in the analytic tradition. Volume III. Society and education (pp. 79-106). London: Routledge. 
Todd, S. (2003). Learning from the other: Levinas, psychoanalysis, and ethical possibilities in education. Albany, NY: State University of New York Press.

Zaviršek, D. (2000). Hendikep kot kulturna travma. Ljubljana: Založba.

\section{About the Author}

Robi Kroflič, Ph.D., is a professor of Theory of Education and Curriculum Theory in the Department for Pedagogy and Andragogy at the Faculty of Arts, University of Ljubljana, Slovenia. He is a lecturer of pedagogy for teachers, theory of education, theories of emotional and behavioral difficulties, preeschool pedagogy and curriculum theories at the undergraduate and graduate level. His basic fields of investigation are: theory of authority and pedagogical eros, moral education, process-oriented planning and planning of educational concepts for public nurseries and schools.

Email: robi.kroflic@guest.arnes.si 